\title{
Antibiotic susceptibilities of indicator bacteria Escherichia coli and Enterococci spp. isolated from ducks in Morogoro Municipality, Tanzania
}

\author{
Henry D. Kissinga ${ }^{1}$, Festo Mwombeki ${ }^{1}$, Khadija Said ${ }^{2}$, Abdul A. S. Katakweba' ${ }^{1}$, Hezron E. Nonga ${ }^{2 *}$ \\ and Amandus P. Muhairwa ${ }^{2}$
}

\begin{abstract}
Objective: To estimate the prevalence of antibiotic resistance in indicator bacteria Escherichia coli and Enterococci isolated from duck faeces in Morogoro Municipality, Tanzania.

Results: Escherichia coli and Enterococcus isolation rates from ducks faeces were 91 and 100\% respectively. The prevalence of antibiotic resistance of E. coli and Enterococcus was 70.3 and $42 \%$, respectively. E. coli resistant to four antibiotics were 28 (30.8\%) and showed high resistance to ampicillin (81.3), tetracycline (75.8) and trimethoprim-sulphamethoxine (62.3). Multiple antibiotic resistance of Enterococcus were more than 65\%. High resistance rates shown by Enterococcus were observed in rifampin (62\%), ampicillin (62\%) and tetracycline (42\%). Almost all farmers (92.3\%) left their ducks to scavenge for food around their houses. Antibiotics used in animal treatments were oxytetracyclines, sulfonamides, penicillin dihydrostreptomycin while in humans were tetracycline, ampicillin, and amoxicillin.
\end{abstract}

Keywords: Ducks, Duck droppings, Use of antibiotics, E. coli, Enterococci, Antibiotic resistance

\section{Introduction}

Antibiotic resistance is an emerging world health problem since many bacteria have developed resistance to commonly used antibiotics and the probable reasons are indiscriminate uses of these medicines. In Tanzania, antibiotics are used for the treatment of diseases in humans and animals and as prophylaxis and growth promoters in livestock [1]. Uses of antibiotics in Tanzania are not controlled; patients and farmers can access any kind of these medicines over the counter without prescriptions [1]. In human medicine, the emergence of resistant bacteria is correlated to over-prescription of antibiotics [2]. The ever-increasing uses of antibiotics are a problem in human medicine and livestock, selection pressure has further increased the advantage of the bacteria to

\footnotetext{
*Correspondence: hezron@suanet.ac.tz; nongahezron@yahoo.co.uk

2 Department of Veterinary Medicine and Public Health, Sokoine

University of Agriculture, P.O. Box 3021, Morogoro, Tanzania

Full list of author information is available at the end of the article
}

acquire, maintain and disperse resistant genes to other bacterial populations [3].

Antibiotic resistance has been studied using indicator bacteria like Escherichia coli and Enterococcus spp. which showed good results $[4,5]$. A study on antibiotic resistance in ducks in Tanzania showed high rate of multidrug-resistant Campylobacter jejuni [6], however, no attempts were done to explain the possible predisposing factors neither the resistant in indicator bacteria. Other studies elsewhere on $E$. coli from ducks showed also high rates of multidrug resistance [7, 8]. Enterococci spp. has been reported to show high resistance to vancomycin [9]. Despite the increase of interest in E. coli and Enterococci $i$ spp. antibiotic resistance studies worldwide, there is no such studies in Tanzania. This study determined the prevalence of antibiotic resistance of E. coli and Enterococci spp. isolated from the scavenging ducks (free ranging) that are clinically healthy in Morogoro Municipality, Tanzania. 


\section{Main text \\ Methods \\ Study area and duck sampling}

This cross sectional study was conducted in Morogoro Municipality between November 2014 and March 2015 where 100 Muscovy ducks (Carina moschata) were sampled from 26 backyard flocks [10]. Study ducks were randomly selected from each flock where $5-10 \%$ of the flock size was sampled [11]. The sampled birds included 86 females and 14 male ducks. Before sampling, basic information on management, feeding, uses and disposal of unused antibiotics were gathered using a questionnaire (Additional file 1). The selected ducks were manually restrained and a sterile cotton swab was inserted into cloaca to collect faecal materials. The samples were stored in cool box with ice pack and transported to the laboratory at Sokoine University of Agriculture for analysis. For consistency, two researchers after were trained by the laboratory technologists on swab sampling from birds did the sampling to all the 100 ducks.

\section{Isolation and identification of E. coli and Enterococci spp.}

Faecal samples were plated on MacConkey agar (Oxoid, Basingstoke, UK) and incubated for $24 \mathrm{~h}$ under aerobic condition for isolation of E. coli [12]. Suspect colonies were further identified based on colonial morphology, Gram stain and biochemical tests [12]. For isolation of Enterococci spp., samples were plated on Slanetz-Bartley agar (Oxoid, Basingstoke, UK) and incubated for $48 \mathrm{~h}$ under aerobic condition and identification based on colonial morphology and biochemical tests [9]. During isolation and identification, E. coli ATCC25922 and Enterococcus faecium ATCC 2912 were included as control strains.

\section{Antibiotic susceptibility}

All the E. coli and Enterococci isolates were tested for antibiotic susceptibility using disk diffusion method and interpreted according to the CLSI [13]. Antimicrobial susceptibility testing was performed to some antibiotics which are commonly used in human medicine in Tanzania. Four antibiotics for $E$. coli were tested at indicated concentrations: ampicillin $10 \mu \mathrm{g}$, cefotaxime $30 \mu \mathrm{g}$, trimethoprim-sulphamethoxine $25 \mu \mathrm{g}$ and tetracycline $30 \mu \mathrm{g}$. Enterococci were tested against ampicillin $10 \mu \mathrm{g}$, erythromycin $15 \mu \mathrm{g}$, rifampin $5 \mu \mathrm{g}$, tetracycline $30 \mu \mathrm{g}$ and trimethoprim-sulfamethoxine $25 \mu \mathrm{g}$. All the antibiotic discs were from Oxoid, Basingstoke, UK.

\section{Ethical considerations}

The permission to carry out this study was granted by the Morogoro Municipal Livestock Officer and ethical approval for the study was given by the Ethical
Committees of Sokoine University of Agriculture, Tanzania. Verbal consent was obtained from each of the farmers prior to sampling.

\section{Results}

Out of 100 faecal samples cultured $91 \%$ had E. coli of which $64(70.3 \%)$ showed resistance to different antibiotics tested (Table 1). Multiple antibiotic resistances shown by $E$. coli were: 28 (30.8\%) isolates to four antibiotics, 35 $(38.5 \%)$ to three antibiotics, $13(14.3 \%)$ to two antibiotics, $11(12.1 \%)$ isolates to one antibiotic. Enterococcus was isolated from all the samples and $42 \%$ showed resistance to different antibiotics tested. Five percent of Enterococcus isolates were resistant to all antibiotics, $13 \%$ to four antibiotics, $21 \%$ to three antibiotics, $26 \%$ to two antibiotics and $28 \%$ to one antibiotic tested. Results on duck management and their possible access to antibiotic residues are summarized in Table 2. Of the 26 farmers interviewed, $92.3 \%$ managed ducks extensively where they accessed to dumping places. No administration of veterinary drugs was reported to ducks but respondents reported to treat other animals by using tetracyclines/ oxytetracycline.

\section{Discussion}

The current study found that the $E$. coli isolation rates was 91\% while all ducks haboured Enterococci and the isolates had high rates of multi-antibiotic resistance. This study shed light that the indicator bacteria from free scavenging ducks in Tanzania can be used in studies of antibiotic resistance. This suggests that the problem of antibiotic resistance is widespread even to bacteria isolates from animals which do not receive antibiotic therapy. This has a public health impact since ducks scavenge for the feed around homestead areas and shed their faecal droppings all over and the resistant bacteria can find their way into the food chain and affect humans or the resistant gene can be transferred to pathogenic bacteria [14].

Table 1 Prevalence (\%) of antibiotic resistance of $E$. coli $(n=91)$ and Enterococcus spp. $(n=100)$ isolated from duck

\begin{tabular}{lll}
\hline Antibiotic tested & \multicolumn{2}{l}{$\begin{array}{l}\text { Number of resistant isolates } \\
\text { (\%) }\end{array}$} \\
\cline { 2 - 3 } & E. coli & Enterococcus spp. \\
\hline Ampicillin & $74(81.3)$ & $62(62)$ \\
Cefotaxime & $57(62.3)$ & - \\
Trimethoprim-sulphamethoxine & $69(75.8)$ & $18(18)$ \\
Tetracycline & $54(59.3)$ & $42(42)$ \\
Erythromycin & - & $19(19)$ \\
Rifampin & - & $62(62)$ \\
\hline
\end{tabular}


Table 2 Duck management and their possible access to antibiotic residues $(n=26)$

\begin{tabular}{|c|c|c|}
\hline Parameter assessed & Response category & Number (\%) \\
\hline \multirow[t]{2}{*}{ Duck flock size } & $5-50$ & $21(80.8)$ \\
\hline & $51-120$ & $5(19.2)$ \\
\hline \multirow[t]{3}{*}{ Duck management (feeding system) } & Extensive & $15(57.7)$ \\
\hline & Intensive given maize bran and kitchen wastes & $2(7.7)$ \\
\hline & Both & $9(34.6)$ \\
\hline \multirow[t]{2}{*}{ Ducks scavenging areas } & Around homestead areas and neighbouring households areas & $21(80.8)$ \\
\hline & Around homestead areas & $5(19.2)$ \\
\hline \multirow[t]{4}{*}{ Number of dumps the ducks access during scavenging } & One dumping place & $6(23.1)$ \\
\hline & Two dumping places & $9(34.6)$ \\
\hline & Three dumping places & $9(34.6)$ \\
\hline & Four dumping places & $2(7.7)$ \\
\hline \multirow[t]{2}{*}{ Duck treatment } & Yes & $0(0.0)$ \\
\hline & No & $26(100.0)$ \\
\hline \multirow[t]{2}{*}{ Keeping other animals apart from ducks } & Yes & $24(92.3)$ \\
\hline & No & $2(7.7)$ \\
\hline \multirow[t]{2}{*}{ Treatment of other animals } & Yes & $13(50.0)$ \\
\hline & No & $13(50.0)$ \\
\hline \multirow[t]{5}{*}{ Antibiotic used in treatment of other animals } & Tetracycline/oxytetracyclines & $4(15.4)$ \\
\hline & Sulfonamides & $3(11.5)$ \\
\hline & Oxytetracyclines, sulfonamides, penicillin dihydrostreptomycin & $2(7.7)$ \\
\hline & Other antibiotic not known & $4(15.4)$ \\
\hline & No treatment & $13(50.0)$ \\
\hline \multirow[t]{4}{*}{ Commonly used antibiotics in humans } & Tetracycline & $4(15.4)$ \\
\hline & Ampicillin & $2(7.7)$ \\
\hline & More than one antibiotic (tetracyclines, ampicillin, amoxicillin, sulphonamides) & $8(30.8)$ \\
\hline & Other antibiotic not known & $12(46.2)$ \\
\hline \multirow[t]{3}{*}{ Drug containers and unused medicine disposal system } & Dump & $13(50.0)$ \\
\hline & Latrines & $7(26.9)$ \\
\hline & Burn & $6(23.1)$ \\
\hline
\end{tabular}

The estimated prevalence of antibiotic resistance in $E$. coli isolated during this study is comparable to resistance reported in Malaysia [15]. In Nigeria, a low prevalence of $8.6 \%$ has been reported probably due to using different antibiotics like ofloxacin, nalidixic acid and gentamycin [7]. The high prevalence of antibiotic resistance observed during this study probably ducks are constantly exposed to antibiotic residues from animal and human discharges because of wide uses $[1,16]$. Studies show that antibiotics used in the food animals are poorly absorbed in the gut and the parent compound are excreted in faeces [17-19]. This is supported by several studies that have reported high levels of antibiotic residues in sewage and animal wastes [20-24]. Therefore, the normal flora in scavenging ducks are constantly exposed to antibiotic residues which makes them develop resistance as it was observed during this study.

The E. coli resistance to ampicillin was the highest (81\%) compared to other antibiotics used in the study similar to previous report in Slovakia where the resistance recorded was $87.8 \%$ [25]. Generally, studies show that $60-70 \%$ of $E$. coli isolates have developed resistance against ampicillin $[18,26]$. This may be caused by too much uses of ampicillin in human practice which its residues are potential sources of environmental contaminations where ducks scavenge for feed. In case of sulphamethoxine, the resistance recorded was $76 \%$ as previously recorded by Van Tuat [27]. The antibacterial resistance shown by tetracycline in this study was 59\% while in Slovakia was $37.5 \%$ [8] and that of Nigeria was 75\% [7]. Interestingly, E. coli also showed antibacterial resistance to cefotaxime at $63 \%$, an antibiotic not commonly used in the treatment of the animals in Tanzania. Ducks may access cefotaxime residues in dumps where human faeces and disposed drug remains are found (Table 2). However, high resistance to cefotaxime has been observed with bacteria isolated from different health facilities sewerage [28]. 
Multiple resistances of $E$. coli to more than one antibiotic were also observed in the study. The findings were too high when compared with the study conducted in Vietnam where multiple antibiotic resistance to $E$. coli was $16.7 \%$ to four antibiotics, to three antibiotics $20 \%$ and to two antibiotics was $23.3 \%$ [27]. This occurrence of multiple drugs resistance suggested that livestock played a role as reservoirs of resistant bacteria for environmental contamination [29]. It has been found that bacterial populations isolated from the gut of animals exposed to antibiotics were found to be five times more likely to be resistant to any given antibiotic. The non-resistant bacteria normally acquire the extra-chromosomal antibiotic resistance plasmids (R-plasmids) from the resistant ones when are in close contact $[18,26,30]$. The observed resistance may be contributed by irrational use of antibiotics which discharges a substantial amount of residues to the environment. Other factors which cause the development of resistance could be the easy availability and rampant use of broad-spectrum antibiotics in the presumptive treatment of infections even in health facilities. Lack of enforcement of regulations on antibiotic use as a part of infection control programmes could have influenced the pattern of resistance results to a considerable degree.

Enterococci spp. are natural commensals of the human and animal gut. All the study ducks had Enterococci spp. in their gut contents which showed $42 \%$ resistance rate to different antibiotics tested. Nevertheless, findings from this study showed high resistance in rifampin (62\%), ampicillin (62\%) and tetracycline (42\%). Multidrug resistance was also observed in more than $65 \%$ of the isolates. As earlier stated, the observed resistance of the bacteria to different antibiotics tested in absence of uses of the medicines in ducks could be due to residues discharged to the environment where ducks scavenge can easily get exposed to antibiotics and other resistant bacteria [20-24]. When resistant bacteria are in contact with the nonresistant ones, exchange of genetic materials can take place and the resistant gene can be acquired. Elsewhere, studies have reported that Enterococci spp. isolated from ducks showed resistance against macrolides and lincosamide antibiotics [31-33]. Nevertheless, Enterococci spp. is intrinsically resistant to several antibiotic groups including cephalosporins and aminoglycosides. In addition, many strains harbour transmissible genetic elements for acquired resistance to various antibiotics like tetracycline [34]. Other antibiotic resistance studies in Enterococci spp. isolated from ducks have been carried out using vancomycin antibiotic [9]. Further susceptibility studies of Enterococci spp. to vancomycin is suggested in future since the antibiotic is nowadays a common drug in human medicine in Tanzania.
The questionnaire study further supports the laboratory observation on high resistance rate shown by $E$. coli and Enterococcus spp. It was observed that antibiotics are widely used in the treatment of animals and humans. Regardless of non-uses of veterinary drugs in dusks, the extensive scavenging management system exposes them to the environment with antibiotic residues and other bacteria from animals and humans, which have been on antibiotics. This is supported by the findings that the observed resistances were to antibiotics that are commonly used in humans and animals (Table 2). Resistance bacteria have been isolated from the variety of sources including sewage discharge and the environment [3537]. Drug remains and containers were haphazardly disposed of in the household surrounding environments which may expose ducks to the antibiotic. Therefore, the intensive management system of ducks can help to minimize the unnecessary exposure of birds to antibiotic residues.

\section{Conclusion}

Generally, antibiotic resistance shown by E. coli and Enterococcus spp. in this study was high. This shows the role played by livestock and chicken which are constantly on antibiotics as potential primary sources of antibiotic resistance genes to bacteria isolated from ducks. Isolating multi-antibiotic resistant E. coli and Enterococcus spp. from ducks serve as potential carriers of antibioticresistant strains to humans and poses a serious problem to the public health.

\section{Limitations}

This study used only 100 duck samples collected from Morogoro Municipality which limits generalization of the results to be used as representative on the status of antimicrobial resistance with E. coli and Enterococcus spp. in ducks in Tanzania. Also the numbers of antibiotic tested were few. Testing for antibiotic susceptibility of bacteria using disk diffusion test method may be inferior to broth microdilution methods. Also, the study did not determine the resistance genotypes in E. coli and Enterococcus spp. which were resistant to different types of antibiotics. Nevertheless, presence of other animals on-site where duck sampling was done acts as confounding factors on the resistance rates observed in bacteria isolates from ducks.

\section{Additional file}

Additional file 1. Questionnaire on duck management, antibiotic uses and disposal in Morogoro Municipality, Tanzania. The questionnaire was used as a data collection tool from small scale duck farmers in Morogoro Municipality, Tanzania. 


\section{Abbreviations}

UK: United Kingdom; CLSI: Clinical and Laboratory Standards Institute; $\mu$ g: microgram; spp: species; SUA: Sokoine University of Agriculture; COSTECH: Commission for Science and Technology.

\section{Authors' contributions}

HDK and FM developed the proposal, collected the samples in the field, did the laboratory work and drafted the manuscript. KS, AASK, HEN and APM corrected the proposal, supervised the sample collection and laboratory work, analysed the data, interpreted the results and provided technical advice and critically reviewed the manuscript. All authors read and approved the final manuscript.

\section{Author details}

${ }^{1}$ Pest Management Centre, Sokoine University of Agriculture, P.O. Box 3010, Morogoro, Tanzania. ${ }^{2}$ Department of Veterinary Medicine and Public Health, Sokoine University of Agriculture, P.O. Box 3021, Morogoro, Tanzania.

\section{Acknowledgements}

The authors extend sincere thanks to Mr. G. Mhamphi and Mrs. Mariam Kitojo for the laboratory assistance. Municipal livestock officer is thanked for granting a permission to carry out this research in ducks in Morogoro Municipality. Duck owners are gratefully acknowledged for their good cooperation during the study.

\section{Competing interests}

The authors declare that they have no competing interests.

\section{Availability of data and materials}

The datasets used and/or analyzed during the current study are available from the corresponding author on reasonable request.

\section{Consent for publication}

Not applicable.

\section{Ethics approval and consent to participate}

The permission to carry out this study was granted by the Executive Directors of Municipality. The Vice Chancellor of Sokoine University of Agriculture (SUA) issued a research permit letter on behalf of the Tanzania Commission for Science and Technology (COSTECH). The Ethical Committee of SUA (Morogoro, Tanzania) approved the research project to be conducted in ducks. Verbal consent which was also approved by the SUA Ethical Committee was obtained from each of the duck keeper after explaining the purpose and importance of the study prior to start of data collection. Participation in this study was voluntary with strict confidentiality of information, freedom to stop participating at any time.

\section{Funding}

This study was funded by the Government of United Republic of Tanzania through Higher Education Students' Loan Board (HESLB).

\section{Publisher's Note}

Springer Nature remains neutral with regard to jurisdictional claims in published maps and institutional affiliations.

Received: 30 October 2017 Accepted: 23 January 2018

Published online: 31 January 2018

\section{References}

1. Katakweba AAS, Mtambo MMA, Olsen JE, Muhairwa AP. Awareness of human health risks associated with the use of antimicrobials among livestock keepers and factors that contribute to selection of antibiotic resistance bacteria within livestock in Tanzania. Livest Rural Res Dev. 2012;24(Suppl 1):170.

2. WHO (World Health Organisation). Use of antimicrobials outside human medicine and resultant antimicrobial resistance in humans. Fact Sheet No. 268; 2002. http://biofarmaka.ipb.ac.id/biofarmaka/2011/Material\%20
of\%20Workshop\%20HerbalNet\%20(Antimicrobial\%20Resistance)\%20 -\%20Use\%20of\%20AM\%20Outside\%20Human\%20Medicine\%20and\%20 Resultant\%20AM\%20Resistance\%20in\%20Humans.pdf.

3. Alan GM, Robin C, Liamthong S. Antibiotic resistance in bacteria associated with food animals: a United States perspective of livestock. Prod Foodborne Pathog Dis. 2007;4(2):115-33.

4. Stone ND, Lewis DR, Lowery HK, Darrow LA, Kroll CM, Gaynes RP, Jernigan JA, McGowan JE Jr, Tenover FC, Richards CL Jr. Importance of bacterial burden among methicillin-resistant Staphylococcus aureus carriers in a long-term care facility. Infect Control Hosp Epidemiol. 2008;29(2):143-8.

5. Neu HC. The crisis in antibiotic resistance. Science. 1992;257:164-73.

6. Nonga HE, Muhairwa AP. Prevalence and antibiotic susceptibility of thermophilic Campylobacter isolates from free range domestic duck (Cairina moschata) in Morogoro municipality, Tanzania. Trop Anim Health Prod. 2010;42(2):165-72. https://doi.org/10.1007/s11250-009-9401-0.

7. Olaitan JO, Shittu OB, Akinliba AA. Antibiotic resistance of enteric bacteria isolated from duck droppings. J Appl Biosci. 2011;45:38-318.

8. Heba L, Kačániová M, Lejková J, Pochop J. Antibiotic resistance of Enterobacteriaceae species associated with faecal bacterial cenosis of ducks. Anim Sci Biotechnol. 2011:44(1):408-14.

9. Shah-Majid M, Azlina AM, Ana-Maria AR, Zaharah B, Norhaliza AH. Occurrence of vancomycin-resistant enterococci in ducks in Malaysia. Vet Rec. 2004;55(21):680-1.

10. Cannon RM, Roe RT. Livestock disease surveys: a field manual for veterinarians. Canberra: Australian Government publishing Services; 1986.

11. Noordhuizen JPTM, Frankena K, Thrusfield MV, Graat EAM. Application of quantitative methods in veterinary epidemiology. 2nd ed. Wageningen: Wageningen Press; 2001. p. 210-48.

12. Damborg P, Sørensen AH, Guardabassi L. Monitoring of antimicrobial resistance in healthy dogs: first report of canine ampicillin-resistant Enterococcus faecium clonal complex 17. Vet Microbiol. 2008;132:190-6.

13. CLSI (Clinical and Laboratory Standards Institute). Performance standards for antimicrobial susceptibility testing; twentieth informational supplement. CLSI document M100-S20. Wayne: CLSI; 2007.

14. Tortorello ML. Indicator organisms for safety and quality-uses and methods for detection: minireview. J AOAC Intern. 2003;86(6):1208-17.

15. Adzitey F, Huda N, Ali GRR. Prevalence and antibiotic resistance of Campylobacter, Salmonella, and L. monocytogenes in ducks: a review. Foodborne Pathog Dis. 2012;9(6):498-505.

16. Nováková I, Kačániová M, Haščik P, Kliment M, Arpášová H. Antibiotic resistance of faecal enterococci in domestic poultry and broilers from commercial farms. Lucřari stiintifice Zootehnie si Biotehnologii. 2009:42:437-41.

17. Alcock RE, Sweetman A, Jones KC. Assessment of organic contaminant fate in wastewater treatment plants I. Selected compounds and physiochemical properties. Chemosphere. 1999;38:2247-62.

18. Sarmah AK, Meyer MT, Boxall AB. A global perspective on the use, sales, exposure pathways, occurrence, fate and effects of veterinary antibiotics (VAs) in the environment. Chemosphere. 2006;65:725-59.

19. Halling-Sørensen $\mathrm{BH}$. Inhibition of aerobic growth and nitrification of bacteria in sewage sludge by antibacterial agents. Arch Environ Contam Toxicol. 2001;40(4):451-60.

20. Hirsch R, Ternes T, Haberer K, Kratz KL. Occurrence of antibiotics in the aquatic environment. Sci Total Environ. 1999;225(1-2):109-18.

21. Christian T, Schneider RJ, Färber HA, Skutlarek D, Meyer MT, Goldbach HE. Determination of antibiotic residues in manure, soil, and surface waters. Clean Soil Air Water. 2013;31(1):36-44.

22. Brown KD, Kulis J, Thomson B, Chapman TH, Mawhinney DB. Occurrence of antibiotics in hospital, residential, and dairy effluent, municipal wastewater, and the Rio Grande in New Mexico. Sci Total Environ. 2006;366(2-3):772-83.

23. Larsson DGJ, de Pedro C, Paxeus N. Effluent from drug manufactures contains extremely high levels of pharmaceuticals. J Hazard Mater. 2007;148(3):751-5

24. Tong $L$, Li P, Wang Y, Zhu K. Analysis of veterinary antibiotic residues in swine wastewater and environmental water samples using optimized SPE-LC/MS/MS. Chemosphere. 2009;74(8):1090-7.

25. Tao R, Ying G, Hao-Chang S, Hong-Wei Z, Jatinder PS. Detection of antibiotic resistance and tetracycline resistance genes in Enterobacteriaceae isolated from the Pearl rivers in South China. Environ Pollut. 2010;158(6):2101-9. 
26. Laxminarayan R, Heymann DL. Challenges of drug resistance in the developing world. BMJ. 2012;344:e1567. https://doi.org/10.1136/bmj.e1567

\section{(Epub 2012/04/12, PMID: 22491075)}

27. Van Tuat C. A study of antimicrobial resistance of Escherichia coli isolated from retail fresh pork in Hanoi, Vietnam. Unpublished Dissertation for Award of MSc. Degree at Chiang Mai University and Freie Universität Berlin, 2007; p. 1-141.

28. Perchere JC. Patients interviews and misuse of antibiotics. Clin Infect Dis. 2001;33(3):S170-3.

29. Sayah RS, Kaneene JB, Johnson Y, Miller RA. Patterns of antimicrobial resistance observed in Escherichia coli isolates obtained from domesticand wild-animal fecal samples, human septage, and surface water. Appl Environ Microbiol. 2005:71:1394-404.

30. Witte W. Medical consequences of antibiotic use in agriculture. Science. 1998;279:996-7.

31. Saikia PK, Dutta GN, Devriese LA, Kalita CC. Characterisation and antimicrobial susceptibility of Enterococcus species from the intestines of ducks in Assam. Res Vet Sci. 1995;58(3):288-9.
32. Van den Braak N, van Belkum A, van Keulen M, Vliegenthart J, Verbrugh $H A$, Endtz HPH. Molecular characterization of vancomycin-resistant Enterococci from hospitalized patients and poultry products in The Netherlands. J Clin Microbiol. 1998;36:1927-36.

33. Devriese LA, leven M, Goossens H, Vandamme P, Pot B, Hommez J, Haesebrouck F. Presence of vancomycin-resistant enterococci in farm and pet animals. Antimicrob Agents Chem. 1996:40:2285-7.

34. Cetinkaya Y, Falk P, Mayhall CG. Vancomycin-resistant enterococci. Clin Microbiol Rev. 2000;13:686-707.

35. Kaspar CW, Burgess JL, Knight IT, Colwell RR. Antibiotic resistance indexing of Escherichia coli to identify sources of fecal contamination in water. Can J Microbiol. 1990;36:891-4.

36. McKeon DM, Calabrese JP, Bissonnette GK. Antibiotic resistant gram-negative bacteria in rural ground water supplies. Water Res. 1995;29:192-8.

37. Mulamattathil SG, Esterhuysen HA, Pretorius PJ. Antibiotic resistant gramnegative bacteria in a virtually closed water reticulation system. J Appl Microbiol. 2000;88:93-937.

\section{Submit your next manuscript to BioMed Central and we will help you at every step:}

- We accept pre-submission inquiries

- Our selector tool helps you to find the most relevant journal

- We provide round the clock customer support

- Convenient online submission

- Thorough peer review

- Inclusion in PubMed and all major indexing services

- Maximum visibility for your research

Submit your manuscript at www.biomedcentral com/submit 